\title{
Penilaian Kerentanan Air Permukaan terhadap Pencemaran di Sub DAS Garang Hilir Berbasis Multi-Indeks
}

\author{
Hermin Poedjiastoeti ${ }^{1}$ \\ Jurusan Teknik Sipil, Fakultas Teknik \\ Universitas Islam Sultan Agung, Semarang, Indonesia
}

\section{Sudarmadji}

Jurusan Geografi Lingkungan, Fakultas Geografi

Universitas Gadjah Mada, Yogyakarta, Indonesia

\section{Sunarto}

Jurusan Geografi Lingkungan, Fakultas Geografi

Universitas Gadjah Mada, Yogyakarta, Indonesia

\section{Slamet Suprayogi}

Jurusan Geografi Lingkungan, Fakultas Geografi Universitas Gadjah Mada, Yogyakarta, Indonesia

Artikel Masuk : 18 Juni 2017

Artikel Diterima : 9 September 2017

Tersedia Online : 29 Desember 2017

\begin{abstract}
Abstrak: Dalam menilai kerentanan air permukaan terhadap pencemaran di Sub DAS Garang Hilir Semarang, dilakukan kajian dengan mendasarkan pada beberapa komponen/indikator lingkungan. Pengukuran kerentanan dengan membuat formulasi indeks kerentanan air permukaan terhadap pencemaran menjadi penting untuk dilakukan, mengingat belum tersusunnya indikator pengaruh pencemaran air permukaan dalam suatu sistem penilaian yang efisien. Oleh karena itu, perlu upaya penilaian kerentanan air permukaan terhadap pencemaran yang berbasis multi-indikator. Indeks Kerentanan Air Permukaan terhadap Pencemaran (IKAPP) disusun berdasarkan lima komponen, yaitu kualitas air (KA), curah hujan (CH), penggunaan lahan dan tutupan vegetasi (PLV), hidrogeometrik sungai (HS) dan kependudukan (KP). Dalam mengembangkan indeks, selanjutnya dibuat grafik subindeks serta pembobotan masing-masing komponen. Penerapan dari penyusunan indeks komposit menghasilkan suatu persamaan IKAPP $=0$,29.IKA + 0,23.IKP + 0,14.ICH + 0,20.IPLV + 0,14.IHS, dan nilai indeks sebesar 73,87 termasuk kategori "agak tinggi" yang merepresentasikan kondisi "rentan" di Sub DAS Garang Hilir. Hal ini menunjukkan bahwa lima komponen terpilih yang digunakan dalam menyusun indeks dapat memberikan informasi yang cukup berguna untuk membuat suatu keputusan dalam pengendalian pencemaran air permukaan.
\end{abstract}

Kata kunci: air permukaan, indeks, indikator, kerentanan, pencemaran

\footnotetext{
1 Korespondensi Penulis: Jurusan Teknik Sipil, Fakultas Teknik, Universitas Islam Sultan Agung, Semarang, Indonesia Email: hermin@unissula.ac.id
} 


\begin{abstract}
Assessing the surface water vulnerability to pollution in the Garang Downstream Watershed Semarang requires a study concerned with some environmental components/indicators. Vulnerability measurement through surface water susceptibility index formulation on pollution is important considering the absence of surface water pollution effect indicators in an efficient assessment system. Therefore, a multi-indicator vulnerability assessment on surface water pollution is necessary. The Surface Water Vulnerability Index to Pollution (SWVIP) is composed of five components, namely water quality (WQ), rainfall (R), land use and vegetation cover $(L V C)$, river hydrogeometric $(R H)$ and population $(P)$. Regarding index development, the subindex graphs and the weighting of each component are created. The application of composite index measurement yields an equation of SWVIP $=0.29$. WQI + $0.23 P I+0.14 R I+0.20 .2 V C I+0.14 . R H I$ and an index value of 73.87 including the "rather high" category that represents the "vulnerable"condition in the Garang Downstream Watershed Semarang. This suggests that the five selected components used in the index creation can provide useful information to decision making in the surface water pollution control.
\end{abstract}

Keywords: index, indicator, pollution, surface water, vulnerability

\title{
Pendahuluan
}

Air permukaan adalah bagian dari air hujan yang tidak mengalami infiltrasi (peresapan) atau air hujan yang mengalami peresapan dan muncul kembali ke permukaan bumi. Air permukaan dapat dibagi menjadi beberapa macam yaitu limpasan, sungai, danau, dan rawa. Salah satu jenis air permukaan yaitu sungai sebagai sumber air yang penting dan banyak dimanfaatkan, sepanjang keberadaannya cukup dalam jumlah dan kualitas untuk berbagai keperluan seperti rumah tangga, irigasi, industri, aktivitas perdesaan dan perkotaan serta kehidupan organisme lainnya dalam suatu ekosistem (Çinar \& Merdun, 2009).

Di dalam suatu sistem Daerah Aliran Sungai (DAS), sungai yang berfungsi sebagai wadah pengaliran air menempati suatu ekosistem terbuka dan berada di posisi paling rendah dalam lanskap bumi. Hal tersebut mengakibatkan sungai lebih mudah dalam mengakumulasi berbagai jenis buangan dari daerah sekitarnya, sehingga menjadikan air sungai sangat rentan terhadap pencemaran yang banyak dipengaruhi oleh aktivitas manusia seperti pembuangan limbah industri (Azrina, Yap, Ismail, Ismail, \& Tan, 2006; Mokaya, Mathooko, \& Leichtfried, 2004), perkebunan, pertanian dan limbah perkotaan (Carpenter et al., 1998; Palmer, 1965), maupun proses alam seperti perubahan iklim, curah hujan dan transportasi sedimen (Ravichandran, 2003). Sungai yang tercemar mengakibatkan terjadinya degradasi pada kualitas air (Bordalo, Nilsumranchit, \& Chalermwat, 2001; Carvalho, Cortes, \& Bordalo, 2011), habitat fisik serta integritas biologi sistem lotik (sungai) (Carpenter et al., 1998; Varol \& Şen, 2009) dan keanekaragaman hayati perairan (Maddock, 1999).

Secara terminologi, kerentanan merupakan kecenderungan suatu entitas mengalami kerusakan (Kaly et al., 1999; Kaly, Pratt, \& Mitchell, 2004). Entitas dapat berupa fisik (manusia, ekosistem, garis pantai) atau konsep yang abstrak (komunitas, ekonomi, negara dan sebagainya) yang dapat mengalami kerusakan. Konsep kerentanan pada awalnya tidak diterapkan secara khusus untuk air permukaan (sungai), namun karena mempunyai relevansi yang tinggi, sehingga dapat diaplikasikan pada sungai. Dalam kajian ini, kerentanan air permukaan terhadap pencemaran dapat diartikan sebagai kemudahan suatu sistem air permukaan (sungai) mengalami kerusakan akibat pencemaran.

Penilaian kerentanan dilakukan untuk mengidentifikasi risiko yang dapat terjadi pada Sub DAS Garang. Salah satu metode yang digunakan dalam menilai kerentanan adalah metode indeks dan overlay (Harter \& Walker, 2001). Indeks atau indikator merupakan alat yang digunakan untuk mereduksi banyak data dan informasi hingga menjadi bentuk yang paling sederhana, tanpa menghilangkan makna esensinya. Indeks mewakili pengukuran agregat dari kombinasi ukuran kinerja, sehingga indeks adalah sintesis dari berbagai faktor menjadi satu faktor yang diberikan (Sainz, 1989). 
Dalam penelitian ini, pemilihan lokasi kajian adalah di Sub DAS Garang Hilir yang secara administratif berada di Kota Semarang. Sub DAS Garang Hilir sebagai bagian dari DAS Garang memiliki potensi sumber daya air dan manfaat yang sangat besar bagi Kota Semarang. Di sisi lain, perkembangan pembangunan menimbulkan permasalahan di wilayah Sub DAS Garang bagian hilir seperti pemanfaatan sempadan sungai untuk permukiman, penurunan kualitas air karena limbah domestik dan industri, dan terjadinya sedimentasi. Oleh karena itu wilayah Sub DAS Garang Hilir dengan Sungai Garang sebagai sungai utamanya perlu dilihat kondisi kerentanannya terhadap terjadinya pencemaran.

Pendekatan secara ekologis dilakukan untuk melihat indikator kerentanan yang digunakan yaitu terkait faktor-faktor yang mempengaruhi pencemaran sungai. Pengukuran kerentanan dengan membuat formulasi indeks kerentanan air permukaan terhadap pencemaran menjadi penting untuk dilakukan, mengingat belum tersusunnya indikator/variabel pengaruh pencemaran air permukaan dalam suatu sistem penilaian yang efisien, sehingga perlu upaya penyusunan suatu instrumen penilaian kerentanan air permukaan terhadap pencemaran yang berbasis multi-indikator. Oleh karena itu tujuan dari penelitian ini adalah merumuskan indikator-indikator penyusun indeks kerentanan terhadap pencemaran sungai di daerah kajian dan memformulasikan indeks kerentanan air permukaan terhadap pencemaran di daerah kajian.

\section{Metode Penelitian}

Formulasi model indeks kerentanan air permukaan terhadap pencemaran (IKAPP) dilakukan melalui beberapa tahap:

a. pemilihan komponen yang ditetapkan sebagai indikator yang sesuai;

b. pengembangan beberapa grafik untuk masing-masing indikator dan perumusan formula secara matematis;

c. pembobotan masing-masing indikator;

d. aplikasi indeks dan penetapan status kerentanan perairan berdasarkan nilai indeks.

Ringkasan pembuatan model indeks kerentanan air permukaan terhadap pencemaran mengikuti alur seperti pada Gambar 1.

\section{Pemilihan Indikator}

Penetapan indikator kerentanan dirumuskan dengan melakukan kajian literatur untuk mengumpulkan sejumlah parameter yang relevan untuk menjadi penyusun indeks kerentanan air permukaan terhadap pencemaran. Beberapa referensi yang digunakan untuk ditelaah dan dipilih indikatornya meliputi: Rahayu, Widodo, van Noordwijk, Suryadi, \& Verbist (2009), tentang pemantauan air di DAS; Kaly, Pratt, \& Mitchell (2004) tentang Indeks Kerentanan Lingkungan; Eimers, Weaver, Terziotti, \& Midgette (2000) tentang metode penilaian zona tak jenuh dan karakteristik DAS dalam penyediaan air di Carolina Utara; dan Brown, McClelland, Deininger, \& O'Connor (1972) tentang Indeks Kualitas Air. Berdasarkan beberapa referensi yang terpilih, kemudian prinsip-prinsip penting diidentifikasi untuk menentukan indikator yang relevan antara lain:

1. spesifik, sehingga dapat secara jelas untuk mengidentifikasi hasil;

2. terukur, sehingga sifatnya menjadi kuantitatif;

3. praktis, sehingga dapat mudah digunakan;

4. tersedia, sehingga pengumpulan data yang diperlukan untuk indikator dapat dilakukan; dan

5. transparan dalam metodologi dan seleksi dengan didasarkan pada standar ilmiah.

Adapun asumsi parameter/indikator serta spesifikasi indikator yang digunakan dalam kerangka kerentanan seperti disajikan pada Tabel 1. 


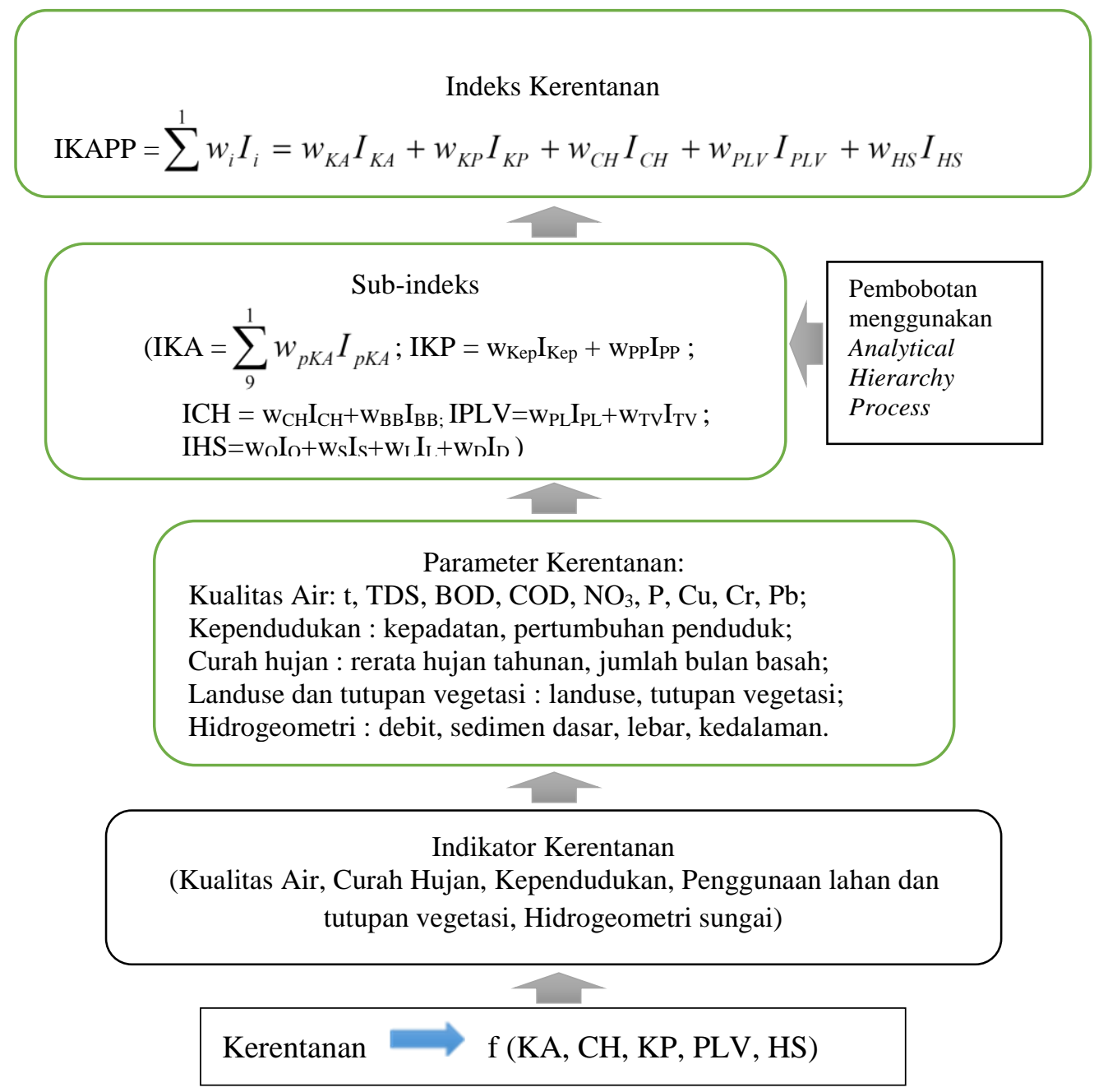

Keterangan:

- IKAPP = Indeks Kerentanan Air Permukaan terhadap Pencemaran; $w=$ bobot; $I=$ Indeks

- $K A=$ Kualitas air; $C H=$ curah hujan; $K P=$ kependudukan; $P L V=$ penggunaan lahan dan tutupan vegetasi; $H S=$ Hidrogeometri sungai

- $p K A=$ parameter kualitas air; $B B=$ bulan basah; Kep $=$ Kepadatan penduduk; $P P=$ pertumbuhan penduduk; $P L=$ penggunaan lahan $; V=$ tutupan vegetasi, $Q=$ debit $; S=$ sedimen dasar; $L=$ lebar sungai; $D=$ kedalaman sungai

Sumber: Modifikasi dari Babel, Pandey, Rivas, \& Wahid (2011)

\section{Gambar 1. Ringkasan Metode Penyusunan Indeks Kerentanan Air Permukaan terhadap Pencemaran}


Tabel 1. Spesifikasi Indikator Penilaian Kerentanan Air Permukaan terhadap Pencemaran

\begin{tabular}{|c|c|c|c|c|}
\hline Indeks & $\begin{array}{l}\text { Indikator \& } \\
\text { Sub-indeks }\end{array}$ & Variabel & Asumsi Hubungan Fungsional & Teknik/Sumber Data \\
\hline \multirow{5}{*}{$\begin{array}{l}\text { Indeks } \\
\text { Kerentanan } \\
\text { Air } \\
\text { Permukaan } \\
\text { terhadap } \\
\text { Pencemaran } \\
\text { (IKAPP) }\end{array}$} & $\begin{array}{l}\text { Kualitas Air } \\
\text { (Indeks } \\
\text { Kualitas Air / } \\
\text { IKA) }\end{array}$ & $\begin{array}{l}\text { - Parameter fisik } \\
\text { - Parameter kimia }\end{array}$ & $\begin{array}{l}\text { - Keberadaan zat/unsur-unsur } \\
\text { dalam air berfungsi menjaga } \\
\text { keberlangsungan proses } \\
\text { biologi dan kimia dalam } \\
\text { sungai }\end{array}$ & $\begin{array}{l}\text { - Data Kualitas Air (KA) } \\
\text { (BLH Provinsi Jateng } \\
\text { 1999-2014) } \\
\text { - Pengukuran lapangan } \\
2015\end{array}$ \\
\hline & $\begin{array}{l}\text { Hidrogeometri } \\
\text { Sungai } \\
\text { (Indeks } \\
\text { Hidrogeometri } \\
\text { Sungai / IHS) }\end{array}$ & $\begin{array}{l}\text { - Lebar sungai } \\
\text { - Kedalaman } \\
\text { sungai } \\
\text { - Kecepatan aliran } \\
\text { sungai } \\
\text { - Ukuran batuan } \\
\text { dasar sungai }\end{array}$ & $\begin{array}{l}\text { Kecepatan aliran sungai } \\
\text { dipengaruhi oleh lebar dan } \\
\text { kedalamannya. Sungai yang } \\
\text { dalam dan lebar dengan } \\
\text { batuan dasar yang relatif } \\
\text { besar memiliki kecepatan } \\
\text { aliran yang lebih besar yang } \\
\text { membantu proses } \\
\text { pengenceran air dari zat } \\
\text { pencemar }\end{array}$ & $\begin{array}{l}\text { - Digital RBI (2001) } \\
\text { - Pengukuran Lapangan } \\
2015\end{array}$ \\
\hline & $\begin{array}{l}\text { Curah Hujan } \\
\text { (Indeks Curah } \\
\text { Hujan / ICH) }\end{array}$ & $\begin{array}{l}\text { - Hujan tahunan } \\
\text { (mm/th) } \\
\text { - Jumlah bulan } \\
\text { basah }\end{array}$ & $\begin{array}{l}\text { Curah hujan yang cukup tinggi } \\
\text { sepanjang musim dapat lebih } \\
\text { cepat mengencerkan air dari zat } \\
\text { pencemar }\end{array}$ & $\begin{array}{l}\text { - Data Curah Hujan }(\mathrm{CH}) \\
\text { 2006-2014 (BMKG, } \\
\text { Dinas PSDA Provinsi } \\
\text { Jawa Tengah) }\end{array}$ \\
\hline & $\begin{array}{l}\text { Penggunaan } \\
\text { lahan dan } \\
\text { Tutupan } \\
\text { Vegetasi } \\
\text { (Indeks } \\
\text { Penggunaan } \\
\text { Lahan dan } \\
\text { Vegetasi / } \\
\text { IPLV) }\end{array}$ & $\begin{array}{l}\text { - Jenis Penggunaan } \\
\text { lahan } \\
\text { - \% Tutupan } \\
\text { vegetasi DAS }\end{array}$ & $\begin{array}{l}\text { - Dominasi penggunaan lahan } \\
\text { seperti permukiman, industri, } \\
\text { pertanian, akan } \\
\text { meningkatkan jumlah limbah } \\
\text { - Semakin sedikit tutupan } \\
\text { vegetasi dalam DAS, } \\
\text { berpotensi meningkatkan } \\
\text { erosi tanah dan sedimentasi } \\
\text { sungai, sehingga } \\
\text { meningkatkan kerentanan } \\
\text { terhadap pencemaran }\end{array}$ & $\begin{array}{l}\text { - Digital RBI (2001), Citra } \\
\text { Landsat (2006- 2015) }\end{array}$ \\
\hline & $\begin{array}{l}\text { Kependudukan } \\
\text { (Indeks } \\
\text { Kependudukan } \\
\text { / IKP) }\end{array}$ & $\begin{array}{l}\text { - Kepadatan } \\
\text { penduduk } \\
\text { - Pertumbuhan } \\
\text { penduduk }\end{array}$ & $\begin{array}{l}\text { - Kepadatan dan pertumbuhan } \\
\text { penduduk yang tinggi } \\
\text { meningkatkan tekanan } \\
\text { terhadap lingkungan }\end{array}$ & $\begin{array}{l}\text { - Kecamatan dalam Angka } \\
\text { dan Kota Semarang } \\
\text { dalam Angka, 2006-2016 } \\
\text { (BPS Kota Semarang) }\end{array}$ \\
\hline
\end{tabular}

Sumber: Analisis Penyusun, 2016

\section{Pembuatan Grafik Sub-indeks dan Rumus Matematis}

Dalam mendapatkan nilai subindeks, IKAPP mengadopsi teknik rescaling kontinyu. Teknik ini menggunakan nilai aktual indikator IKAPP yang dihitung pada kisaran 0-100. Untuk melakukan ini nilai ambang maksimum dan minimum untuk setiap indikator ditentukan berdasarkan target atau tolok ukur tertentu. Target atau tolok ukur ini diperoleh dari tinjauan pustaka. Nilai maksimum dan minimum indikator berdasarkan pada:

1. baku mutu kualitas: ambient atau stream;

2. rata-rata temporal; dan

3. rata-rata spasial/geografis.

Untuk menghasilkan nilai indeks tunggal, keragaman data dan indikator perlu distandardisasi dalam suatu unit yang sama. Tahir (2010) menggunakan lima tingkatan (1-5), nilai tengah sebagai nilai sedang, nilai terendah dan tertinggi sebagai batas bawah dan batas atas. 


\section{Pembobotan}

Setiap parameter komponen memiliki peran spesifik atau kepentingan relatif di antara parameter yang ditunjukkan oleh bobot parameter dengan kisaran 1-5. Menurut Villa \& McLeod (2002), salah satu pendekatan yang dapat digunakan dalam memberikan bobot adalah matriks perbandingan berpasangan yang biasa digunakan pada Analytical Hierarchy Process (AHP) yang dikembangkan oleh Saaty (1980). Matriks perbandingan berpasangan menggambarkan pengaruh relatif setiap elemen terhadap masing-masing tujuan atau kriteria yang setingkat di atasnya.

\section{Aplikasi Indeks dan Penetapan Status Kerentanan Perairan}

Setelah dilakukan analisis dan evaluasi terhadap model yang dibentuk akan diketahui apakah model tersebut sudah sesuai dengan tujuan yang ingin dicapai. Apabila belum akan dilakukan perbaikan, dan apabila sesuai akan diaplikasikan pada Sungai Garang yang telah dipilih dalam penelitian ini. Rentang nilai indeks antara 0-100 mengandung arti nilai 0 untuk kondisi paling buruk/rentan dan nilai 100 untuk kondisi baik (tidak rentan) (Aidi, 2010).

\section{Hasil dan Pembahasan}

\section{Area Studi}

Penelitian ini berlokasi di Sub DAS Garang Hilir Semarang. Sub DAS Garang Hilir merupakan bagian dari DAS Garang dengan sungai utamanya adalah Sungai Garang. Luas Sub DAS Garang Hilir 2.448,19 ha atau 4,6 \% dari keseluruhan luas DAS Garang yang mencapai 52.964,46 ha.

Sungai Garang di bagian hilir memiliki pola meander di sebelah hulu Bendung Simongan, sedangkan di sebelah hilir Bendung Simongan berupa sudetan (kanal) hingga muara (laut). Aliran Sungai Garang secara perencanaan tata ruang telah dilindungi oleh kawasan perlindungan setempat berupa bantaran sungai. Namun, menurut Khristanto (2015), pola ruang tersebut dinilai belum efektif dalam melindungi kondisi sungai, khususnya terkait dengan kualitas airnya. Alih fungsi lahan yang terjadi di DAS Garang dinilai turut mempengaruhi kondisi perairan Sungai Garang. Selain adanya alih fungsi lahan di DAS Garang, aliran anak sungai di DAS Garang masih mendapatkan beban pencemaran yang terus berlanjut dari aktivitas domestik, industri maupun pertanian, serta industri kecil pengolahan ikan.

\section{Formulasi Indeks Komposit Kerentanan Air Permukaan terhadap Pencemaran}

Model indeks kerentanan yang dikonstruksi dalam penelitian ini adalah model statis indeks kerentanan lingkungan. Model statis indeks kerentanan lingkungan dimaksudkan untuk menghitung indeks kerentanan saat ini (sesaat). Penemuan komponen dari indeks dan parameter diimplementasikan untuk mendapatkan indeks di daerah penelitian.

Indeks Kerentanan Air Permukaan terhadap Pencemaran (IKAPP) merupakan komposit dari Indeks Kualitas Air, Indeks Curah Hujan, Indeks Kependudukan, Indeks Penggunaan Lahan dan Tutupan Vegetasi serta Indeks Hidrogeometrik Sungai. Persamaan Indeks Kerentanan Air Permukaan terhadap Pencemaran (IKAPP) ditulis sebagai persamaan (1). 


$$
I K A P P=\sum_{5}^{1} w_{i} I_{i}=w_{K A} I_{K A}+w_{K P} I_{K P}+w_{C H} I_{C H}+w_{P L V} I_{P L V}+w_{H S} I_{H S}
$$

Keterangan:

IKAPP = Indeks Kerentanan Air Permukaan terhadap Pencemaran; $w=$ bobot; I = Indeks; $I_{K A}$

$=$ Indeks Kualitas Air; $I_{C H}=$ Indeks Curah Hujan; $I_{K P}=$ Indeks Kependudukan; $I_{P L V}=$ Indeks

Penggunaan Lahan dan Tutupan Vegetasi; $I_{H S}=$ Indeks Hidrogeometri Sungai

Dalam mengidentifikasi status kerentanan terhadap pencemaran berdasarkan nilai indeks, masing-masing parameter/indikator kerentanan (kualitas air, curah hujan, kependudukan, penggunaan lahan dan tutupan vegetasi serta hidrogeometrik sungai). Nilai indeks kerentanan kemudian diklasifikasikan ke dalam lima kategori. Kisaran nilai indeks kerentanan dan kategori kerentanan yaitu: 0-20 rendah (tidak rentan); 21-40 agak rendah (kurang rentan); 41-60 sedang (cukup rentan); 61-80 agak tinggi (rentan) dan 81-100 tinggi (sangat rentan).

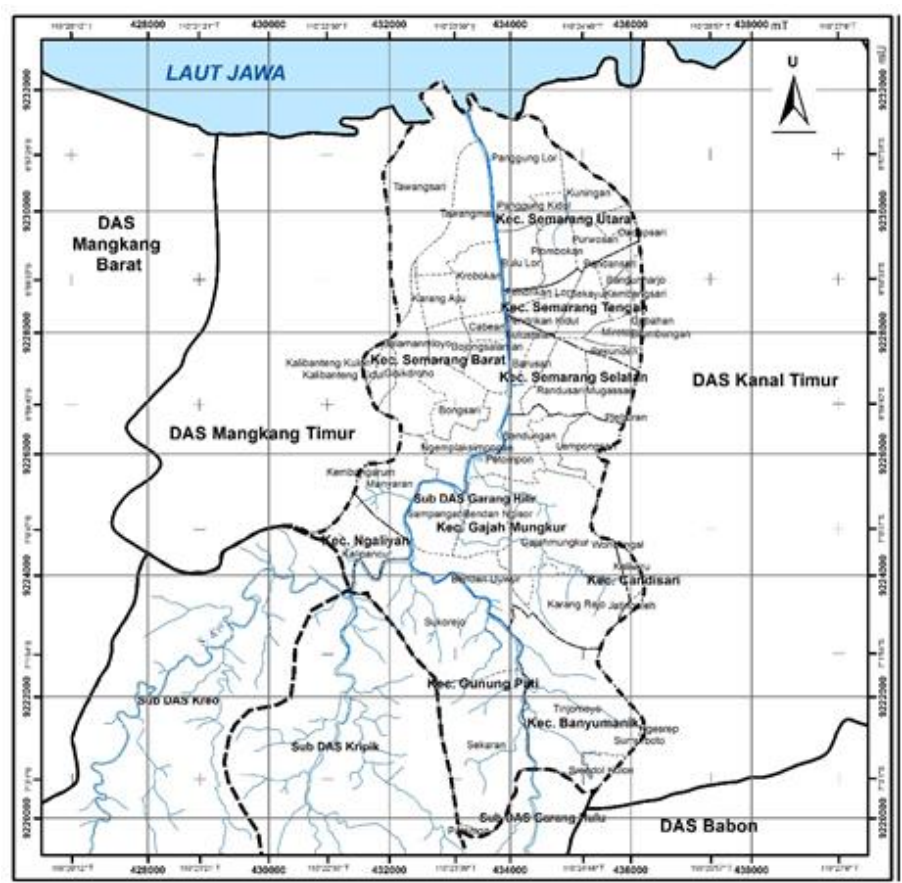

Sumber: Disalin dari Peta RBI (2001), Peta Batas DAS Garang-BP DAS Pemali Jratun (2003), Citra Landsat (2015)

\section{Gambar 2. Sub DAS Garang Hilir Semarang}

\section{Indeks Kualitas Air}

Penentuan Indeks Kualitas Air (IKA) menggunakan pendekatan analitis objektif data sekunder kualitas air hasil pemantauan oleh Badan Lingkungan Hidup (BLH) Provinsi Jawa Tengah di lima lokasi titik pantau mulai September 1999-Juni 2014. Penentuan IKA dilakukan dalam tiga tahap yaitu pemilihan parameter dominan dengan bantuan Analisis Faktor, pembobotan dengan bantuan AHP serta pembuatan grafik subindeks dengan mengkombinasikan beberapa standar kualitas air. Berdasarkan ketiga tahap tersebut, diperoleh indeks kualitas air yang merupakan akumulasi dari parameter temperatur, residu terlarut, $\mathrm{BOD}, \mathrm{COD}$, total fosfat sebagai $\mathrm{P}, \mathrm{NO}_{3}$ sebagai $\mathrm{N}$, krom, tembaga, dan timbal. 
Berdasarkan pembuatan grafik subindeks dan pembobotan masing-masing parameter, maka persamaan IKA ditulis sebagai persamaan (2).

$$
\begin{aligned}
I K A= & w_{t} I_{t}+w_{T D S} I_{T D S}+w_{B O D} I_{B O D}+w_{C O D} I_{C O D}+w_{P} I_{P} \\
& +w_{N} I_{N}+w_{C r} I_{C r}+w_{C u} I_{C u}+w_{P b} I_{P b}
\end{aligned}
$$

atau

$$
\begin{gathered}
I K A=0,12 q i-t+0,15 q i-T D S+0,19 q i-B O D+0,13 q i-C O D+0,07 q i-P \\
+0,08 q i-N+0,09 q i-C r+0,09 q i-C u+0,08 q i-P b
\end{gathered}
$$

\begin{tabular}{|c|c|c|c|c|c|c|}
\hline Komponen & Indikator & Bobot & Formula & $\begin{array}{l}\text { X Rata- } \\
\text { Rata }\end{array}$ & $\begin{array}{c}\text { Indeks } \\
\text { Sub- } \\
\text { indikator }\end{array}$ & Indeks \\
\hline \multirow{9}{*}{$\begin{array}{c}\text { Kualitas } \\
\text { Air }\end{array}$} & Temperatur & 0,12 & $y=-1,2964 x^{2}+70,161 x-853,7$ & 28,9 & 91,19 & 10,94 \\
\hline & Residu terlarut & 0,15 & $y=-0,0686 x+172,86$ & 754,29 & 121,12 & 18,17 \\
\hline & BOD & 0,19 & $y=-10,357 x+122,5$ & 5,23 & 68,33 & 12,98 \\
\hline & COD & 0,13 & $y=-0,7904 x+106,67$ & 28,62 & 84,05 & 10,93 \\
\hline & $\begin{array}{l}\text { Total P sebagai } \\
\text { Pospat }\end{array}$ & 0,07 & $y=-59,524 x+113,57$ & 0,17 & 103,45 & 7,24 \\
\hline & $\mathrm{NO}_{3}$ sebagai $\mathrm{N}$ & 0,08 & $y=-2,47 x+113,5$ & 0,81 & 111,4993 & 8,92 \\
\hline & Krom $(\mathrm{Cr})$ & 0,09 & $y=6817,9 x^{2}-2177,3 x+188,72$ & 0,004 & 125,98 & 11,34 \\
\hline & Tembaga $(\mathrm{Cu})$ & 0,09 & $y=-654,76 x+106,43$ & 0,01 & 99,88 & 8,99 \\
\hline & Timbal $(\mathrm{Pb})$ & 0,08 & $y=-1100 x+130$ & 0,03 & 97 & 7,76 \\
\hline \multicolumn{2}{|c|}{ Indeks Kualitas Air } & 1 & & & & 97,27 \\
\hline
\end{tabular}

Berdasarkan persamaan tersebut, maka nilai dari indeks kualitas air sebesar 97,27 dapat dilihat pada Tabel 2.

Tabel 2. Perhitungan Indeks Kualitas Air Sungai

Sumber: Analisis Data, 2016

Keterangan: y adalah indeks dari tiap parameter; $\mathrm{x}$ adalah jumlah/nilai atau persentase dari parameter

\section{Indeks Curah Hujan}

Indeks curah hujan (ICH) adalah akumulasi dari komponen ketebalan hujan (kh) dan banyaknya bulan basah (bb). Penentuan ICH berdasarkan data curah hujan dari tahun 20062014 di lima stasiun hujan di sekitar daerah penelitian, yaitu Stasiun Hujan Madukoro, Stasiun Klimatologi Semarang, Stasiun Hujan Kalisari, Stasiun Hujan Simongan dan Stasiun Hujan Sumur Jurang. Rumus matematis ICH yang dihasilkan setelah pembobotan dan pembuatan grafik sub-indeks ditulis sebagai persamaan (3).

$$
I C H=w_{k h} I_{k h}+w_{b b} I_{b b} \text { atau } I C H=0,54 q i-k h+0,46 q i-b b .
$$

Berdasarkan persamaan tersebut, maka nilai dari indeks curah hujan dapat dilihat pada Tabel 3, yaitu sebesar 45,92. 
Tabel 3. Perhitungan Indeks Curah Hujan

\begin{tabular}{ccccccc}
\hline Komponen & Indikator & Bobot & Formula & $\begin{array}{c}\mathbf{X} \\
\text { rata- } \\
\text { rata }\end{array}$ & $\begin{array}{c}\text { Indeks } \\
\text { Sub- } \\
\text { indikator }\end{array}$ & Indeks \\
\hline \multirow{2}{*}{ Curah Hujan } & $\begin{array}{l}\text { Rerata hujan } \\
\text { tahunan }\end{array}$ & 0,54 & $\mathrm{y}=0,0501 \mathrm{x}-50,28$ & 2004,50 & 50,15 & 27,08 \\
& Bulan Basah & 0,46 & $\mathrm{y}=6,7247 \mathrm{x}+0,6171$ & 6 & 40,97 & 18,84 \\
\hline \multicolumn{2}{c}{ Indeks Curah Hujan } & 1,00 & & & & $\mathbf{4 5 , 9 2}$ \\
\hline Sumber: Analisis Data, 2016 & & & & &
\end{tabular}

\section{Indeks Kependudukan}

Penentuan indeks kependudukan (IKP) didasarkan pada kepadatan penduduk dan laju pertumbuhan penduduk. Data kependudukan berasal dari data penduduk di wilayah yang secara administrasi masuk dalam Sub-DAS Garang Hilir, meliputi sembilan kecamatan yaitu Semarang Utara, Semarang Tengah, Semarang Selatan, Semarang Barat, Gajahmungkur, Banyumanik, Ngaliyan, Candisari dan Gunungpati dengan beberapa cakupan wilayah kelurahan. Selanjutnya setelah pembobotan dan pembuatan grafik sub-indeks, berikut adalah rumus IKP yang ditulis sebagai persamaan (4).

$$
I K P=0,50 q i-K P+0,50 q i-P P
$$

Berdasarkan persamaan tersebut, maka nilai dari indeks kependudukan dapat dilihat pada Tabel 4, yaitu nilai sebesar 57,38.

Tabel 4. Perhitungan Indeks Kependudukan

\begin{tabular}{clccccc}
\hline Komponen & Indikator & Bobot & Formula & $\begin{array}{c}\mathbf{X} \\
\text { rata- } \\
\text { rata }\end{array}$ & $\begin{array}{c}\text { Indeks } \\
\text { Sub- } \\
\text { indikator }\end{array}$ & Indeks \\
\hline \multirow{2}{*}{ Kependudukan } & $\begin{array}{l}\text { Kepadatan } \\
\text { laju } \\
\text { pertumbuhan }\end{array}$ & 0,5 & $\mathrm{y}=0,0416 \mathrm{x}+17,574$ & 1.357 & 74,03 & 37,01 \\
\hline \multicolumn{1}{c}{ Indeks Kependudukan } & 1,00 & $\mathrm{y}=24,795 \mathrm{x}+10,983$ & 1,2 & 40,74 & 20,37 \\
\hline Sumber: Analisis Data, 2016 & & & & & $\mathbf{5 7 , 3 8}$ \\
\hline
\end{tabular}

\section{Indeks Penggunaan Lahan dan Tutupan Vegetasi}

Dalam perhitungan nilai indikator lahan, dalam hal ini yang menjadi sub-indikator adalah penggunaan lahan dan tutupan vegetasi, sehingga indeks penggunaan lahan dan tutupan vegetasi (IPLV) merupakan akumulasi dari komponen penggunaan lahan (pl) dan persentase tutupan vegetasi (tv). Pembobotan dilakukan dengan menggunakan matriks perbandingan berpasangan. Berdasarkan pembobotan dan pembuatan grafik subindeks, berikut adalah rumus Penggunaan Lahan dan Tutupan Vegetasi (IPLV), yang ditulis sebagai persamaan (5).

$$
I P L V=w_{p l} I_{p l}+w_{t v} I_{t v} \quad \text { atau } \quad I P L V=0,55 q i-P L+0,45 q i-T V .
$$

Berdasarkan persamaan tersebut, maka nilai dari indeks penggunaan lahan dan tutupan vegetasi dapat dilihat pada Tabel 5, dengan nilai sebesar 76,07. 
177 Penilaian Kerentanan Air Permukaan terhadap Pencemaran ...

Tabel 5. Perhitungan Indeks Penggunaan Lahan dan Tutupan Vegetasi

\begin{tabular}{|c|c|c|c|c|c|c|}
\hline Komponen & Indikator & Bobot & Formula & $\begin{array}{c}X \\
\text { rata- } \\
\text { rata }\end{array}$ & $\begin{array}{c}\text { Indeks } \\
\text { Sub- } \\
\text { indikator }\end{array}$ & Indeks \\
\hline \multirow{2}{*}{$\begin{array}{l}\text { Landuse dan } \\
\text { tutupan } \\
\text { vegetasi }\end{array}$} & $\begin{array}{l}\text { Jenis } \\
\text { penggunaan } \\
\text { lahan }\end{array}$ & 0,55 & $y=-10,091 x+107,09$ & 3,88 & 67,94 & 37,37 \\
\hline & $\begin{array}{l}\text { Tutupan } \\
\text { vegetasi }\end{array}$ & 0,45 & $y=25 x-22$ & 4,32 & 86,00 & 38,70 \\
\hline \multicolumn{2}{|c|}{$\begin{array}{c}\text { Indeks Penggunaan Lahan dan } \\
\text { Tutupan Vegetasi }\end{array}$} & 1,00 & & & & 76,07 \\
\hline
\end{tabular}

\section{Indeks Hidrogeometrik Sungai}

Penentuan indeks hidrogeometrik sungai (IHS) didasarkan pada persentase sedimen dasar sungai, debit, lebar dan kedalaman sungai. Selanjutnya setelah pembobotan dan pembuatan grafik sub-indeks, berikut adalah rumus IHS yang ditulis sebagai persamaan (6).

$$
I H S=0,31 q i-Q+0,21 q i-S+0,24 q i-L+0,24 q i-D .
$$

Berdasarkan persamaan tersebut, maka nilai dari indeks hidrogeometrik sungai dapat dilihat pada Tabel 6. Hasil perhitungan indeksnya adalah 77,33.

Tabel 6. Perhitungan Indeks Hidrogeometrik Sungai

\begin{tabular}{clccccc}
\hline Komponen & Indikator & Bobot & Formula & $\begin{array}{c}\mathbf{X} \\
\text { rata- } \\
\text { rata }\end{array}$ & $\begin{array}{c}\text { Indeks } \\
\text { Sub- } \\
\text { indikator }\end{array}$ & Indeks \\
\hline \multirow{2}{*}{ Hidrogeometrik } & Sedimen dasar & 0,21 & $\mathrm{y}=-34 \mathrm{x}+120,33$ & 0,05 & 118,63 & 24,91 \\
& Debit & 0,31 & $\mathrm{y}=14,965 \ln (\mathrm{x})+40,488$ & 10,15 & 75,21 & 23,31 \\
& Lebar & 0,24 & $\mathrm{y}=1,4535 \mathrm{x}+25,6$ & 27,72 & 65,89 & 15,81 \\
& Kedalaman & 0,24 & $\mathrm{y}=28,998 \mathrm{x}+27,808$ & 0,95 & 55,36 & 13,29 \\
\hline Indeks Hidrogeometrik & 1,00 & & & & $\mathbf{7 7 , 3 3}$ \\
\hline
\end{tabular}

Sumber: Analisis Data, 2016

\section{Indeks Kerentanan Air Permukaan terhadap Pencemaran}

Penentuan komposit indeks kerentanan air permukaan terhadap pencemaran (IKAPP) dengan mendasarkan pada persamaan (1), setelah pembobotan komponen maka persamaan akan ditulis sebagai persamaan (7).

$$
I K A P P=0,29 . I K A+0,23 \cdot I K P+0,14 \cdot I C H+0,20 . I P L V+0,14 . I H S .
$$

Hasil perhitungan indeks kerentanan air permukaan terhadap pencemaran ditunjukkan pada Tabel 7. 
Tabel 7. Perhitungan Komposit Indeks Kerentanan Air Permukaan terhadap Pencemaran

\begin{tabular}{|c|c|c|c|}
\hline Komponen & Subindeks & Bobot & Indeks \\
\hline Kualitas air & 97,27 & 0,29 & 28,21 \\
\hline Kependudukan & 57,38 & 0,23 & 13,20 \\
\hline Curah hujan & 45,92 & 0,14 & 6,43 \\
\hline Penggunaan lahan dan tutupan vegetasi & 76,07 & 0,20 & 15,21 \\
\hline Hidrogeometrik sungai & 77,33 & 0,14 & 10,83 \\
\hline IKAPP & & 1,00 & $\mathbf{7 3 , 8 7}$ \\
\hline
\end{tabular}

Sumber: Analisis Data, 2016

Berdasarkan hasil perhitungan IKAPP, nilai indeks adalah 73,87. Hal ini menggambarkan wilayah Sub DAS Garang Hilir termasuk ke dalam kategori "agak tinggi/ rentan". Jika dilihat dari nilai sub-indeks, maka pengaruh yang paling besar adalah dari kondisi kualitas air, kemudian komponen hidrogeometrik sungai, penggunaan lahan dan tutupan vegetasi, kependudukan serta nilai yang paling kecil adalah komponen curah hujan.

Hasil pengolahan data time series kualitas air di Sungai Garang Hilir yang diwujudkan dalam model, memberikan gambaran bahwa sembilan parameter kualitas air yang digunakan dalam penyusunan indeks berhubungan atau mempengaruhi nilai IKA. Nilai IKA ini dapat mencerminkan kondisi perairan Sungai Garang Hilir dengan sumber pencemar yang berasal dari limbah domestik, pertanian dan industri, yang terwakili dari nilai parameter-parameter yang dihasilkan dari aktivitas-aktivitas tersebut.

Berdasarkan data curah hujan di lima stasiun penakar hujan di sekitar daerah penelitian antara tahun 2006-2015, hujan rata-rata di Sub DAS Garang Hilir 2.031,27 mm/tahun dan jumlah bulan basah adalah sembilan bulan. Hal ini menunjukkan wilayah Sub DAS Garang Hilir termasuk daerah basah dan kandungan lengas tanah tinggi. Hasil analisis terhadap nilai indeks curah hujan menunjukkan nilai indeks sebesar 45,92 yang termasuk dalam kategori cukup rentan (sedang). Hal tersebut mengindikasikan bahwa kemampuan curah hujan di daerah penelitian dalam membawa polutan adalah sedang.

Secara temporal, data penggunaan lahan dari tahun 2002-2015 di daerah penelitian cenderung mengalami perubahan luas tiap tahunnya. Jika dilihat dari jenis penggunaan lahannya, Sub DAS Garang bagian hilir didominasi permukiman yaitu sebesar 70,10\%. Permukiman mengalami kenaikan luas dalam penggunaannya, sementara sawah mengalami pengurangan luas yang paling tinggi $(-77 \%)$. Perubahan lahan menjadi permukiman disebabkan oleh kenaikan jumlah dan pertumbuhan penduduk.

Dalam suatu sistem DAS, penduduk memiliki peran penting karena berhubungan langsung dengan kegiatan pemanfaatan lahan yang bertujuan untuk memenuhi kebutuhan. Hubungan fungsional antara jumlah penduduk dan tingkat kerentanan adalah berbanding lurus. Kaly et al., (1999) mengemukakan bahwa semakin tinggi pertumbuhan penduduk di suatu wilayah akan meningkatkan kerentanan wilayah tersebut. Hal ini juga sejalan dengan apa yang disampaikan oleh Tompkins et al., (2005) yang menyebutkan bahwa wilayah dengan penduduk yang padat akan memiliki kerentanan yang lebih tinggi dibandingkan dengan wilayah yang berpenduduk rendah. Badan Pusat Statistik Provinsi Jawa Tengah (2015) menyatakan bahwa efek samping dari meningkatnya pertambahan penduduk adalah tingginya pencemaran air, udara dan tanah, buruknya kondisi pemukiman, serta padatnya penduduk.

Indeks hidrogeometrik sungai menunjukkan nilai sebesar 77,33. Pengaruh komponen hidrogeometrik sungai terhadap kerentanan terhadap pencemaran adalah dalam hal proses pemurnian sendiri sungai, karena faktor hidrogeometrik sungai menentukan kemampuan pulih diri (self-purification). Jika dilihat dari kondisi hidrogeometrik sungai, misalnya lebar dan kedalaman, Sungai Garang Hilir termasuk sungai yang memiliki lebar dan kedalaman 
yang hampir seragam dan debit yang tidak terlalu tinggi (rata-rata debit tahunan 40 $\mathrm{m}^{3} /$ detik), sedangkan sampling material dasar Sungai Garang Hilir lebih banyak didominasi jenis pasir.

\section{Kesimpulan}

Berdasarkan temuan studi yang diperoleh, maka dapat disimpulkan bahwa indikatorindikator IKAPP yaitu kualitas air, curah hujan, penggunaan lahan dan tutupan vegetasi, hidrogeometrik sungai dan kependudukan. IKAPP merupakan suatu alat (tool) yang secara ilmiah dapat mengkuantifikasi situasi secara lokal yang berhubungan dengan kerentanan terhadap pencemaran.

Formulasi IKAPP yang terbentuk berdasarkan lima komponen sebagai indikator terpilih dan pembobotan berdasarkan nilai peringkat adalah:

$$
I K A P P=0,29 . I K A+0,23 . I K P+0,14 . I C H+0,20 . I P L V+0,14 . I H S
$$

Implementasi penilaian kerentanan (IKAPP) berbasis multi-indeks (indeks kualitas air, indeks kependudukan, indeks curah hujan, indeks penggunaan lahan dan tutupan vegetasi dan indeks hidrogeometri sungai) di Sub DAS Garang Hilir menghasilkan nilai IKAPP sebesar 73,87, yang menunjukkan bahwa daerah penelitian termasuk ke dalam kategori "agak tinggi/ rentan". Nilai indeks komposit ini secara umum dapat menunjukkan indikasi kerentanan. Sebagai catatan, bahwa kerangka kerja penyusunan indeks kerentanan air permukaan terhadap pencemaran ini secara potensial dapat diterapkan untuk wilayah dengan karakteristik wilayah yang serupa.

\section{Ucapan Terima Kasih}

Ucapan terima kasih disampaikan kepada seluruh instansi Pemerintah Kota Semarang dan Pemerintah Provinsi Jawa Tengah yang terkait dengan penelitian ini, atas bantuan data/informasi, izin dan bantuan teknis selama kegiatan penelitian. Penelitian ini merupakan bagian dari penelitian disertasi penulis pertama atas bantuan pendanaan dari Unissula, serta Beasiswa Pasca Sarjana dan Hibah Disertasi Doktor yang diberikan oleh Kementerian Riset, Teknologi dan Pendidikan Tinggi.

\section{Daftar Pustaka}

Aidi, M. N. (2010). Indeks Kualitas Lingkungan Hidup. Bogor: Departemen Statistika, Institut Pertanian Bogor. Retrieved from http://repository.ipb.ac.id/handle/123456789/68972.

Azrina, M. Z., Yap, C. K., Ismail, A. R., Ismail, A., \& Tan, S. G. (2006). Anthropogenic impacts on the distribution and biodiversity of benthic macroinvertebrates and water quality of the Langat River, Peninsular Malaysia. Ecotoxicology and Environmental Safety, 64(3), 337-347. doi: 10.1016/j.ecoenv.2005.04.003.

Babel, M. S., Pandey, V. P., Rivas, A. A., \& Wahid, S. M. (2011). Indicator-based approach for assessing the vulnerability of freshwater resources in the Bagmati River Basin, Nepal. Environmental Management, 48(5), 1044-1059. doi: 10.1007/s00267-011-9744-y.

Badan Pusat Statistik Provinsi Jawa Tengah. (2015). Data dan Informasi Lingkungan Hidup Jawa Tengah 2013. Badan Pusat Statistik Provinsi Jawa Tengah.

Bordalo, A. A., Nilsumranchit, W., \& Chalermwat, K. (2001). Water quality and uses of the Bangpakong River (Eastern Thailand). Water Research, 35(15), 3635-3642. doi: 10.1016/S0043-1354(01)00079-3.

Brown, R. M., McClelland, N. I., Deininger, R. A., \& O’Connor, M. F. (1972). A water quality index -crashing the psychological barrier. In W. . Thomas (Ed.), Indicators of Environmental Quality. Boston, MA: Springer. doi: 10.1007/978-1-4684-1698-5_15. 
Carpenter, S., Caraco, N., Correll, D. ., Howarth, R. W., Sharpley, A. N., \& Smith, V. H. (1998). Nonpoint pollution of surface waters with phosphorus and nitrogen. Ecological Application, 8(January 1998), 559-568. doi: 10.1890/1051-0761(1998)008[0559:NPOSWW]2.0.CO;2.

Carvalho, L., Cortes, R., \& Bordalo, A. A. (2011). Evaluation of the ecological status of an impaired watershed by using a multi-index approach. Environmental Monitoring and Assessment, 174(1-4), 493-508. doi: 10.1007/s10661-010-1473-9.

Çinar, Ö., \& Merdun, H. (2009). Application of an unsupervised artificial neural network technique to multivariant surface water quality data. Ecological Research, 24(1), 163-173. doi: 10.1007/s11284-008-0495-z.

Eimers, J. L., Weaver, J. C., Terziotti, S., \& Midgette, R. W. (2000). Methods of Rating Unsaturated Zone and Watershed Characteristics of Public Water Supplies in North Carolina. North Carolina. Retrieved from https://pubs.usgs.gov/wri/wri994283/pdf/report.pdf.

Harter, T., \& Walker, L. G. (2001). Assessing Vulnerability of Groundwater. (L. Rollins, Ed.). California. Retrieved from https://www.scribd.com/document/269083852/Assessing-Vulnerability-of-Ground-Water.

Kaly, U., Briguglio, L., Mcleod, H., Schmall, S., Pratt, C., \& Pal, R. (1999). Environmental Vulnerability Index (EVI) to summarise national environmental vulnerability profiles.

Kaly, U., Pratt, C., \& Mitchell, J. (2004). The Environmental Vulnerability Index (EVI). SOPAC Technical Report 384.

Khristanto, A. (2015). Kali Garang Masih Mampukah? Retrieved November 4, 2016, from http://www.pdamkotasmg.co.id/berita/114-seminar-kaligarang-dan-tata-kelola-air-di-kotasemarang.html.

Maddock, I. (1999). The importance of physical habitat assessment for evaluating river health. Freshwater Biology, 41(2), 373-391. doi: 10.1046/j.1365-2427.1999.00437.x.

Mokaya, S. K., Mathooko, J. M., \& Leichtfried, M. (2004). Influence of anthropogenic activities on water quality of a tropical stream ecosystem. African Journal of Ecology, 42, 281-288. doi: 10.1111/j.13652028.2004.00521.x.

Palmer, W. C. (1965). Meteorological Drought. U.S. Weather Bureau, Research Paper No. 45. Washington DC: U.S Weather Bureau. Retrieved from https://www.ncdc.noaa.gov/temp-andprecip/drought/docs/palmer.pdf.

Rahayu, S., Widodo, R. H., van Noordwijk, M., Suryadi, I., \& Verbist, B. (2009). Monitoring Air di Daerah Aliran Sungai. Bogor. Retrieved from http://www.worldagroforestry.org/downloads/publications/PDFs/B16396.PDF.

Ravichandran, S. (2003). Hydrological influences on the water quality trends in Tamiraparani Basin, South India. Environmental Monitoring and Assessment, 873), 293-309. doi: 10.1023/A:1024818204664.

Saaty, T. L. (1980). The Analytical Hierarchy Process. New York: McGraw-Hill.

Sainz, P. (1989). An index of social welfare. In F. Bracho (Ed.), Towards a New Way to Measure Development, Report on the International Meeting on More Effective Development Indicators (pp. 156-160). Caracas, Venezuela.

Tahir, A. (2010). Formulasi Indeks Kerentanan Lingkungan Pulau-Pulau Kecil: Kasus Pulau Kasu-Kota Batam, Pulau Barang Lompo-Kota Makasar dan Pulau Saonek-Kabupaten Raja Ampat. Sekolah Pascasarjana Institut Pertanian Bogor.

Tompkins, E. L., Nicholson-Cole, S. A., Hurlston, L.-A., Boyd, E., Hodge, G. B., Clarke, J., ... Varlack, L. (2005). Surviving Climate Change in Small Islands: A guidebook. October. Norwich. Retrieved from https://inis.iaea.org/search/search.aspx?orig_q=RN:37003788.

Varol, M., \& Şen, B. (2009). Assessment of surface water quality using multivariate statistical techniques: A case study of Behrimaz Stream, Turkey. Environmental Monitoring and Assessment, 159(1-4), 543-553. doi: 10.1007/s10661-008-0650-6.

Villa, F., \& McLeod, H. (2002). Environmental vulnerability indicators for environmental planning and decisionmaking: Guidelines and applications. Environmental Management, 29(3), 335-348. doi:10.1007/s00267001-0030-2. 